Chirurgia (2021) 116: 387-398

No. 4, July - August

Copyright@ Celsius

http://dx.doi.org/10.21614/chirurgia.116.4.387

\title{
Regenerative Liver Surgery - ALPPS and Associated Techniques
}

\author{
Florin Botea ${ }^{1}$, Alexandru Barcu', Cosmin Verdea', Patryk Kambakamba ${ }^{2,3}$, Irinel Popescu' and Michael Linecker ${ }^{4 *}$ \\ 'Department of General Surgery and Liver Transplantation, Fundeni Institute Bucharest, Romania \\ ${ }^{2}$ Department of Hepatobiliary Surgery and Liver Transplantation, St. Vincent`s University Hospital, Dublin, Ireland \\ ${ }^{3}$ Department of Surgery, Cantonal Hospital Glarus, Switzerland \\ ${ }^{4}$ Department of Surgery and Transplantation, University Medical Center Schleswig-Holstein, Campus Kiel, Germany
}

\author{
*Corresponding author: \\ Michael Linecker, MD, PhD \\ Department of Surgery and \\ Transplantation, University Medical \\ Center Schleswig-Holstein \\ Campus Kiel Arnold-Heller-Straße 3 \\ Haus C 24105 Kiel, Germany \\ Phone: +49 (0)1520 / 4521132 \\ E-mail: Michael.Linecker@uksh.de

\section{Abbreviations:} \\ ALPPS: associating liver partition \\ and portal vein ligation for \\ staged hepatectomy; \\ Ang: angiopoietin; \\ APEAL: associating portal embolization \\ and artery ligation \\ CRLM: colorectal liver metastases; \\ ECM: extracellular matrix: \\ EGF: epidermal growth factor: \\ FGFs: fibroblast growth factors: \\ FLR: $\quad$ future liver remnant; \\ GBC: $\quad$ gallbladder cancer; \\ HCC: hepatocellular carcinoma; \\ HGF: $\quad$ hepatocyte growth factor; \\ HIDA: hepatobiliary iminodiacetic \\ acid; \\ ICG: indocyanine green; \\ ICG-PDR: indocyanine green plasma \\ disappearance rate;
}

Received: 25.07.2021

Accepted: 15.08 .2021

\section{Rezumat}

\section{Chirurgia regenerativă a ficatului - ALPPS și tehnici asociate}

Hepatectomia este singurul tratament potențial curativ al tumorilor hepatice, dar rămâne o provocare în cazul leziunilor multiple bilobare şi a celor situate în vecinătatea hilului hepatic şi/sau a venelor hepatice. Chirurgia regenerativă a ficatului foloseşte capacitatea unică a acestuia de a creşte după pierdere tisulară şi privarea vasculară. Toate conceptele incluse în această strategie terapeutică vizează creşterea rezecabilității tumorilor hepatice prin stimularea procesului de hipertrofiere a ficatului restant. Multe dintre aceste tehnici au evoluat în ultimele decenii. ALPPS (partiționarea hepatică asociată cu ligatura de vena portă pentru hepatectomie în doi timpi) este o tehnică avansată care combină ligatura venei porte drepte şi partiționarea parenchimatoasă, ce a dat naştere la numeroase variante, toate cu scopul comun de a extinde rezectabilitatea. Acest articol trece în revistă tehnicile disponibile în prezent pentru chirurgia hepatică regenerative, concentrându-se asupra ALPPS, analizând mecanismele de regenerare hepatică, indicațiile, avantajele, dezavantajele, rezultatele şi perspectivele acesteia.

Cuvinte cheie: chirurgie hepatică regenerativă, ALPPS (partiționarea hepatică asociată cu ligatura de vena portă pentru hepatectomie în doi timpi), metastaze hepatice de origine colorectală, carcinoma hepatocelular, colangiocarcinom 


$\begin{array}{ll}\text { IGF: } & \text { insulin-like growth factor; } \\ \text { IHCC: } & \text { intrahepatic cholangiocarcinoma; } \\ \text { IL-6: } & \text { interleukin 6; } \\ \text { INR: } & \text { international normalized ratio; } \\ \text { ISGLS: } & \text { International Study Group of Liver Surgery } \\ \text { LVD: } & \text { liver venous deprivation; } \\ \text { MELD: } & \text { model of end-stage liver disease; } \\ \text { miRNAs: } & \text { circulating microRNAs; } \\ \text { NASH CRN: } & \text { non-alcoholic steato-hepatitis Clinical } \\ & \text { Research Network } \\ \text { NELM: } & \text { neuroendocrine liver metastases; } \\ \text { PCNA: } & \text { nuclear non-histone protein critical } \\ & \text { for DNA synthesis; } \\ \text { PHCC: } & \text { perihilar cholangiocarcinoma; } \\ \text { PSALPPS: } & \text { parenchymal sparing ALPPS; } \\ \text { PVE: } & \text { portal vein embolization; } \\ \text { PVL: } & \text { portal vein ligation; } \\ \text { RALPPS: } & \text { radiofrequency assisted ALPPS } \\ \text { RAPID: } & \text { Resection and partial liver segment 2-3 } \\ & \text { transplantation with delayed total } \\ & \text { hepatectomy } \\ \text { RAVAS: } & \text { heterotopic transplantation of } \\ & \text { segments } 2 \text { and } 3 \text { using the splenic } \\ & \text { vein and artery after splenectomy } \\ \text { SFSS: } & \text { and with delayed total hepatectomy; } \\ \text { SLV: } & \text { Small for size syndrome; } \\ \text { TNF- } \alpha: & \text { Standard liver volume; } \\ \text { TSH: } & \text { Tumor necrosis factor alpha; } \\ \text { VEGF: } & \text { Two-stage hepatectomy; } \\ & \text { vascular endothelial growth factor. } \\ \end{array}$

\section{Introduction}

Hepatectomy is the only potentially curative treatment of hepatic tumors. In particular, multiple bilobar lesions and those located in the vicinity of the hepatic hilum and the hepatic veins remain a challenge as this surgery involves a high risk of insufficient remnant liver volume, which can lead to postoperative liver failure. Regenerative liver surgery, with its most advanced concept, ALPPS (associated liver partition and portal vein ligation for staged hepatectomy) was introduced to increase the resectability of hepatic tumors by stimulating the growth of the liver parenchyma that is planned to remain after the radical resection, the socalled future liver remnant (FLR). This article will lead through the development of regenerative liver surgery, the different techniques, particularly related to ALPPS, touch the topic of liver failure in this context, give some molecular insights in liver regeneration, and will give an outlook on possible future perspectives of regenerative liver surgery.

\section{Development of Regenerative Liver Surgery}

In 1920, Rous and Larimore provided the first experimental evidence of contralateral liver hypertrophy following portal vein ligation in rabbits (1). In the late 1980s, Makuuchi et al. devised preoperative portal vein embolization (PVE) to induce growth of the FLR, thereby reducing the risk of liver failure after extended hepatectomy. In this context the deportalized liver acts as an auxiliary liver contributing to the overall liver function until the FLR has grown enough to take over full liver function $(2,3)$. Although PVE is an easy applicable strategy with a low morbidity and mortality, the maximum volume increase of the FLR is limited to approximately $40 \%$ (4). Failure of technically successful PVE is thought be due to portal collateralization and neoangiogenesis of the deportalized hemiliver from hilar vessels and from the contralateral hemiliver. 
Later, the concept of two-stage hepatectomy (TSH) was introduced, consisting of two sequential operations to remove multiple bilobar lesions otherwise impossible to remove by a single hepatectomy (5). First described by Adam et al, the two sequential operations were performed without growth induction by portal vein occlusion (5). Jaeck et al (6) and Belghiti et al (7) followed up this concept and added growth induction by PVE and PVL to TSH.

TSH can be performed in two technical variations (8):

\section{TSH without PVE or portal vein ligation (PVL)}

The liver lobe with the highest tumor burden (usually the right one) is resected during the first stage, inducing hypertrophy of the contralateral hemiliver. During the second stage, complete tumor clearance of the FLR is performed, usually by limited non-anatomical resections

\section{TSH with PVL/PVE}

The less affected hemiliver, representing the FLR (usually the left one) is cleared of tumors during the first stage, in combination with preoperative / interstage PVE or intraoperative PVL. During the second stage, the lobe with the highest tumor burden (deportalized lobe) is removed after obtaining sufficient hypertrophy of the FLR.

Both strategies do have a certain risk of tumor progression in the interstage interval (the interval between the two operations) that may impede the second (radical) operation. Resection rates of TSH are usually up to $70 \%$ $(5,6)$.

To further increase resectability, Schnitzbauer et al. combined portal vein ligation with in-situ liver partition to induce an accelerated liver hypertrophy of the FLR (9). The procedure was subsequently called ALPPS (10). This procedure enables a FLR increase of $80 \%$ and more, as opposed to approximately $40 \%$ in PVE/PVL (11), and reduces the interstage interval to 1-2 weeks.

A further refinement of PVE is PVE+Seg.IV. This technique adds embolization of liver segment IV portal branches, which results in a greater FLR hypertrophy when compared to PVE alone, ranging from 47 to $54 \%$ instead of 26 to $38 \%$ (12). However, this procedure involves a high risk of injuries of the left portal vein and segmental portal branches of the FLR (13).

Liver venous deprivation (LVD), also called bi-embolization, is a relatively new concept consisting of simultaneous PVE and hepatic vein embolization in the same hemiliver to induce growth of the FLR. This approach is based on the prevention of portal collateralization and neoangiogenesis of the deportalized hemiliver, which is very likely due to the combined portal hyper-flow and limited venous outflow on the contralateral growing hemiliver. Adding venous outflow occlusion on the side of portal inflow occlusion, increases the portal pressure inside the liver impeding the portal collateralization at this level. LVD may potentially avoid morbidity and mortality of ALPPS, but seems to stay inferior in terms of growth of the FLR $(14,15)$.

Another technique of vascular deprivation is the combination of PVE and artery ligation, the so-called APEAL (associating portal embolization and artery ligation to induce rapid liver regeneration in staged hepatectomy), consisting in right portal vein embolization followed by partial right hepatic artery ligation and devascularization of the inferior part of segment IV (without parenchymal transection) during the first stage surgery (16). A major disadvantage of this technique is that deprivation of vascular inflow can lead to substantial hepatic necrosis. This is the reason why APEAL is rarely used.

\section{ALPPS variants and technical refinements}

ALPPS initially recorded unacceptable postoperative mortality rates going up to $15 \%$ (9, 17). Main complications were bile leaks, septic complications and liver failure. The latter was considered to occur as a result of a potentially too short interstage interval of one weeks leading to sufficient liver hypertrophy, but insufficient function with immature parenchyma (18). 
Over time, a series of modifications have been proposed to make this procedure safer and more efficient:

\section{Delayed ALPPS}

The interstage interval between the first and second stage surgery was prolonged form 7-9 days to 14-21 days, delaying the second operation to give the FLR the necessary time to mature its function. This modification led to a significant decrease of postoperative complications $(19,20)$.

\section{Partial ALPPS}

Incomplete parenchymal transection (50\% to $80 \%$ ) during first stage surgery (21) avoids complications associated with complete transection (bleeding, biliary fistula and infectious complications of the ischemic segment IV). This variant decreased morbidity and mortality compared to conventional ALPPS, while still inducing FLR hypertrophy of at least $50 \%(21,22)$. This is now a very commonly used modification of ALPPS.

\section{Segment IV portal pedicle-sparing ALPPS}

Preservation of the main portal pedicles of segment IV during liver transection in stage 1 avoids ischemia at this level (23).

$P V E-A L P P S$

Avoidance of hilar dissection during first stage surgery, which is needed for right portal vein ligation. Extensive hilar dissection is known to increase the risk of operative injuries of hilar structures during the second stage of surgery as a result of dense adhesions and/or fibrosis induced by dissection (22). More so, this maneuver leaves tumor lesions located close to the hilum untouched. Following "no touch" techniques using PVE have been proposed:

- transhepatic approach of the right portal vein (RPV), preoperatively or intraoperatively (hybrid ALPPS) (24);

- RPV approach via the inferior mesenteric (mini-ALPPS) (25) or ileocecal portal vein (TIPE ALPPS / ALPTIPS) (26).

\section{PsALPPS}

Increasing the FLR by shifting the transection plane in favor of the FLR. This is particularly relevant, when conventional ALPPS is not feasible due to insufficient FLR. Possible scenarios are:

- Shifting the transection plane to the Cantlie's line (particularly in case of perihilar cholangiocarcinoma) (26);

- Shifting the transection plane through segment IV, using intraoperative guidance, preserving part of this segment along with the left lateral section (Botea et al, submitted).

\section{RALPPS, Tourniquet ALPPS}

Replacing the transection during the first stage:

- with an avascular plane created using intraoperative ablative techniques: Radiofrequency-assisted liver partition with portal vein ligation for staged hepatectomy (RALPPS) (27);

- with a tourniquet placed around the parenchymal transection plane using the hanging maneuver (tourniquet ALPPS) (28). While easy to perform, it leads to high risk of operative adverse events during the second stage (severe adhesion /fibrosis around the hepatic hilum, involves parenchymal transection, not performed during the first stage).

\section{Minimally invasive ALPPS}

- Laparoscopic ALPPS, which applies the same principles as the open approach (29), or customized to minimal invasive approach, with partial transection during first stage, PVE after stage 1, and hepatectomy completion during the second stage (SMART-ALPPS) (30);

- Robotic ALPPS $(31,32)$.

\section{ALPPS with ligation of the middle hepatic vein}

Further enhancement of FLR hypertrophy by ligating the middle hepatic vein during the first stage (33). 


\section{Monosegment ALPPS}

This variant pushes the limit of the FLR down to only one liver segment (occasionally with the auxiliary segment 1). Successful cases have been reported for segments $2,3,4$ and $6(34,35)$.

\section{Rescue ALPPS}

This is rather an ALPPS strategy than an ALPPS variant. Rescue ALPPS is a valid option after PVE failure (36).

\section{Patient Selection for ALPPS}

ALPPS is an excellent strategy in the treatment of colorectal liver metastases (CRLM) (37-40), but also a valid indication for intrahepatic cholangiocarcinoma (IHCC) (41), neuroendocrine liver metastases (NELM) (42), and other rare indications, such as lymphoma (43). However, in case of hepatocellular carcinoma (HCC), particularly in liver cirrhosis $(44,45)$, perihilar cholangiocarcinoma (PHCC) $(46,47)$ and gallbladder cancer (GBC) significantly higher morbidity and mortality rates have been reported (48) and further investigation on the role of ALPPS in these tumor entities is needed. For example, in case of HCC, 90-day mortality was very high when compared to CRLM (31 vs. 7\%). Moreover, survival was significantly reduced in patients older than 61 years $(44,45)$. Liver transection on a cirrhotic liver is the main source for complications in case of HCC, while on a liver with dilated bile ducts and/or cholangitis is the main source of complication in case of GBC and PHCC. Particularly for PHCC, but useful also for any tumor involving the liver hilum, no touch techniques to avoid hilum dissection and consequent tumor exposure were devised based on portal vein embolization, described above $(24,25,48)$.

Routine preoperative evaluation (including blood routine test, coagulation test, and cardiopulmonary assessment) is mandatory. The Child-Pugh classification system combined with Model of End-Stage Liver Disease (MELD) scoring system are most used to assess basic liver function, particularly in cirrhotics.
Common thresholds are a FLR/Standard liver volume (SLV) of least $20 \%$ in normal liver parenchyma, at least $30 \%$ in patients with chemotherapy, and at least $40 \%$ in otherwise abnormal background liver. Other criteria are FLR/Body weight (BW) above $0.5 \%$ in normal liver parenchyma, and above $0.8 \%$ in otherwise abnormal background liver (49). Liver biopsy and pathological examination may be performed, evaluating the NASH CRN scoring system (at least F2 defining the abnormal liver) (50). Indocyanine green plasma disappearance rate may also be used with a cutoff value of $[(\mathrm{FLR} / \mathrm{SLV}) \times \mathrm{ICG}-\mathrm{PDR}]$ under $5 \%$.

Contraindications for ALPPS are unresectable extrahepatic tumor, unresectable tumor on FLR, impaired liver function with liver cirrhosis above compensated Child A cirrhosis and portal hypertension (HPVG $>10$ $\mathrm{mmHg}$ ), and severe comorbidities, Child-Pugh Grade not over A 24 (49).

Data on long-term oncological outcome of ALPPS is limited. However, in case of CRLM, which by far the most frequent indication for ALPPS, reported overall survival rates vary from 28 to $54 \%$ at 3 years to 32 to 58 at 5 years (51). ALPPS in IHCC showed 3-year overall survival of $21.4 \%$, with better results in case of R0 resection and single lesions (41). In NELM 2-year overall survival rates of $95.2 \%$ were reported (42). In case of $\mathrm{HCC}$, the 5-year overall survival was $46.8 \%(44,45)$. More long-term outcome data is needed to evaluate outcomes of ALPPS in GBC and PHCC.

\section{Alternatives to Regenerative Liver Surgery}

Alternatives techniques to regenerative liver surgery are parenchyma sparing techniques, such as enhanced ultrasound-guided one stage hepatectomy $(52,53)$, adding local ablation to hepatectomy (54), and hepatectomy with vascular resection and reconstruction (55).

Particularly, one stage hepatectomy is based on a different concept to approach multiple and/or large liver lesions. Instead of enlarging the FLR as much liver parenchyma as possible is preserved, based on precise anatomical understanding, and use of intra- 
operative ultrasound (56). Minimizing the resection margins to $1 \mathrm{~mm}$ (57), and even 0 $\mathrm{mm}$ margin for tumor in contact with major vessels (for CRLM, HCC, but not for IHCC) (58-60), these approaches help to further increase resectability. How these procedures compare to regenerative surgery in terms of long-term oncological outcome has not been addressed sufficiently so far.

\section{Posthepatectomy Liver Failure}

Liver failure after liver resection is a lifethreatening complication that occurs in 1.2 to $32 \%$ after major liver resection (61-63). Internationally, a 90-day mortality 5\% after major liver resection is widely accepted in specialized liver centers. Pushing liver resection to volumetric and functional grey-zones may overexert the regenerative capacity of the liver and put the patient at risk for liver failure presenting with encephalopathy, coagulopathy, prolonged hyperbilirubinemia, and early postoperative death in the worstcase scenario. This syndrome is called "small for-size syndrome" (SFSS), a term adopted from liver transplantation. SFSS is often defined by a total serum bilirubin $>100 \mu \mathrm{mol} / \mathrm{l}$, INR $>2$, and encephalopathy grade 3 or 4 , provided that at least two of these criteria occur in the first postoperative week for 3 consecutive days. Technical, immunological, or infectious causes must be excluded (64). Other criteria to define liver failure after extensive resection are the "50-50 criteria", which are characterized by a prothrombin time under $50 \%$ and serum bilirubin over $50 \mu \mathrm{ml} / \mathrm{L}$ on the fifth postoperative day, predicting more than $50 \%$ mortality rate after hepatectomy (65). The ISGLS (International Study Group of Liver Surgery) criteria have been proposed to grade postoperative liver failure in grade A, B, and $\mathrm{C}$. These criteria are defined as an increased INR and hyperbilirubinemia on, or after, the fifth postoperative day (62). Grade A does not require any change of the clinical management, Grade B requires specific medical treatment, and Grade $\mathrm{C}$ requires invasive treatment.
To reduce the risk of this serious complication, it is widely agreed that the FLR is at least $20 \%$ of the original liver size in patients with normal liver parenchyma, and $30-50 \%$ or even higher in patients with impaired liver parenchyma, such as liver steatosis, steatohepatitis, chronic hepatitis, chemotherapyassociated liver injury or cirrhosis (66). Besides the standard static methods like serum parameters as bilirubin, INR, albumin, and scores including MELD and Child-Pugh scores, dynamic (quantitative) tests were developed for better assessment of liver function. The indocyanine green (ICG) retention rate test measures plasma retention of an intravenously given dye, which is eliminated hepatically. A plasma retention at 15 minutes of less than $14 \%$ is considered safe for liver resection, while over $20 \%$ is considered a contraindication (67). The $\mathrm{LiMAx}^{\circledR}$ test is based on the hepatocyte-specific metabolism of the ${ }^{13} \mathrm{C}$-labelled methacetin, which is also administered intraveneously. This radionuclide is converted into ${ }^{13} \mathrm{CO} 2$, which is exhaled and measured by the $\operatorname{LiMAx}^{\circledR}$ machine by analyzing the exhaled air of the patient. A severely impaired liver function is considered to correspond to a value of ${ }^{13} \mathrm{CO} 2$ $<140 \mu \mathrm{g} / \mathrm{kg} / \mathrm{h})(68)$. Hepatobiliary scintigraphy (hepatobiliary iminodiacetic acid; HIDA) is another test, which can determine regional liver function. This is particularly important when assessing the FLR. HIDA scan works with 99mtechnetium-labeled mebrofenin, which is administered intravenously, taken up by the hepatocyte (In normal individuals, the uptake is 100\%) and excreted in bile. A minimum of $2.69 \% / \mathrm{min} / \mathrm{m}^{2}$ of radioactive tracer in bile, measured with the gamma camera, is considered sufficient for safe surgery $(3,19)$.

Despite adequate liver preoperative assessment, various other factors influence the regeneration capacity contributing to the risk of liver failure, such as age, comorbidities, and previous chemotherapy (patient-related factors), other conditions of the liver parenchyma, which are not obvious at the time of surgery, such as fibrosis and cholestasis, and some surgery-related factors, such as more 
extensive resection the preoperatively planned (e.g. additional metastasectomies or tumor ablations), injuries of the vascular and or biliary structures of the FLR, blood loss, ischemia reperfusion injury after vascular clamping, and post-resectional portal hypertension (69-72).

Therapeutic approaches to overcome the postoperative liver failure focus on mitigating liver damage and improving the liver cell proliferation. However, these approaches are ongoing experimental research. Up to date there is no licensed therapy of liver failure, except transplantation, is available. Therefore, prevention of SFSS by accurately choosing the appropriate surgical strategy is vital. Thorough assessment of liver volume and function are important tools to decreases the risk of SFSS. More so, no tests to accurately evaluate the regenerative capacity of the liver are currently available in clinical practice. Identification of factors promoting liver regeneration, such as circulating epithelial cells, cell-free nucleic acids, specific species of DNA and RNA etc., in liquid-biopsy samples are possible options in the future $(73,74)$. Although an abundance of experimental data on different pathways and mediators of liver regeneration are currently available, translation of these makers to assess liver function into clinical practice is poor. Further developments in these field are necessary to avoid SFSS.

\section{Mechanistic Insights of Liver Growth Induction}

The regenerative capacity of the liver parenchyma is a unique phenomenon already acknowledged by the ancient Greeks. There are a number of redundant pathways and mediators that enable recovery of its metabolic and synthetic functions after liver resection. Depending on the extent of resection, the period for restoration of liver functions after resection usually varies between 5 to 7 days. When recovery is not possible due to various factors, liver failure occurs. Therefore, is essential to understand fundamental mechanisms of liver regenera- tion to be able to prevent and treat the liver failure when that occurs. All mediators implicated in liver regeneration are potential predictive biomarkers for liver regeneration capacity, but almost none of them are available in clinical practice. The class mediators known to be involved in this process are: platelets (75); growth factors, such as hepatocyte growth factor (HGF) $(76,77)$, epidermal growth factor (EGF) (78), vascular endothelial growth factor (VEGF) (79), insulin-like growth factor (IGF) (80), fibroblast growth factors (FGFs) (81), angiopoietin (Ang) -1 and -2 (82), and TGF-61 (83); cytokines (84), such as tumor necrosis factor alpha (TNF- $\alpha)(85)$, and interleukin 6 (IL-6) $(86,87)$; extracellular matrix (ECM) (88); immunohistochemical markers for cell proliferation, such as PCNA (nuclear non-histone protein critical for DNA synthesis) and $\mathrm{Ki}^{-67}$ (89); circulating microRNAs (miRNAs), such as the iR-122, miRNA-130b$5 p$ and miR-431-5p $(90,91)$.

It seems that hypertrophy is based on the mature functioning cells that proliferates in the FLR induced by the above mentioned mediators (92), only in response to injury (93). In this setting, almost all (about 95\%) hepatic cells re-enter the cell cycle inducing DNA synthesis in 12-24 hours ( $\mathrm{S}$ phase), with complete restoration of human liver mass after less than 2 cycles of replication in all cells (93). DNA synthesis starts from periportal space towards the central vein. Most of the hypertrophy process occurs during the first 3 days after resection, and completes after 5 to 7 days (94). Activation of cyclin D1 induces the progression of cell cycle through G1 and entry into $S$ phase (95).

Hypertrophy is also stimulated by hemodynamic changes (96), particularly by alterations in portal flow (97). In case of portal vein embolization (PVE) or ligation (PVL), the flow is redirected toward the contralateral hemiliver, stimulating its hypertrophy. This process fails if recanalization of the occluded portal flow occurs via neo-collaterals feeding from the hilum (portal cavernoma) and from the FLR (98). ALPPS prevents the latter by transecting the parenchyma, separating the FLR from the 
deportalized liver. In addition to that, the injury itself further stimulates hypertrophy. This process was experimentally demonstrated on pigs (99), but also in the clinical setting (100). ALPPS stimulates liver regeneration by combining portal flow changes and parenchymal transection, generating a systematic response that induces hepatocyte proliferation and remodeling. ALPPS increases the portal pressure more than conventional PVE/PVL (101), but may be similar when compared to modified PVE involving the segment 4 (102).

ALPPS leads to an increased proliferation of hepatocytes compared to PVL as evidenced by Ki-67 expression and liver mass gain (103, 104). Moreover, ALPPS strongly activates TNF- $\alpha$ and HGF, which in turn activate JNK and MAPK-ERK pathways, also inducing the expression of cyclin D1 (105). Messenger RNA (mRNA) levels of cytokines, and cytokineinduced neutrophil chemoattractant - 1 (CINC1) are higher in liver tissue following ALPPS as compared to PVL. This also applies for VEGF and interferon gamma expression and early infiltration of liver by inflammatory cells (101, 106). In ALPPS, genomic evaluation revealed significant up-regulation of IL-6mRNA and TNF- $a-m R N A$ after the first stage (103); also the number of Kupffer cells increases in the same period (107). All of this change are indicators for increased inflammatory activity.

Histologically, hepatocyte brightness and sinusoidal narrowing were more frequently encountered in the FLR after ALPPS than in PVE, while hepatocyte cell density was greater and hepatocyte size was smaller. In the deportalized liver, hepatocyte atrophy, degeneration or necrosis, sinusoidal dilation, fibrosis and congestion were more frequently observed in ALPPS. However, mitochondria and endoplasmic reticulum seem to be reduced in the FLR of ALPPS compared to PVE, indicating a possible cell immaturity in the setting of ALPPS (18). Interestingly, while ALPPS is clearly superior to PVE/PVL in terms of hypertrophy in adults, in children it seems to be fairly equal (108), emphasizing the particular regenerative capacity of the liver at this age.
The main drawback of liver regeneration in oncological patients a potential stimulation of tumor recurrence after liver resection - a major clinical issue affecting around $50 \%$ of cases (109). This may be due to circulating cancer cells and/or dormant micrometastases (110). The regenerative process may stimulate tumor cell detachment and migration within the liver remnant or the systemic circulation, promoting intra- or extrahepatic tumor recurrence. The tumor dormancy probably occurs due to a equilibrium between proliferation and apoptosis, regulated by a series of factors, such as angiogenic factors (VEGF, angiopoietin), growth factors (HGF, EGF), matrix proteins (thrombospondin), hypoxia-inducible factor 1 alpha (HIF1a), immunological factors (HLA class I antigens), oncogenes, suppressor genes and phenotypic characteristics. The regeneration induced by liver resection may disrupt this equilibrium through its mediators mentioned above, creating a stimulating environment for the dormant micrometastases and probably leading to their activation (111). Certain mediators are considered to particularly promote tumor recurrence, such as HGF, EGF, VEGF, TGF-81 and MMPs (52).On the contrary, an ALPPS mouse model with implanted tumor cells has shown that ALPPS induced liver regeneration does not appear to enhance tumor growth in the setting of CRLM (112).

\section{Future of Regenerative Liver Surgery}

To further push the limits of regenerative liver surgery, a concept based on the combination of liver resection and transplantation, emerging from auxiliary transplantation, was proposed. The RAPID concept consists of liver resection (left lateral sectionectomy or left hemihepatectomy) and partial liver segment II-III transplantation (harvested from deceased or living donors), followed by delayed total hepatectomy. $(113,114)$. A variation of this technique, named RAVAS, was presented in a single case. This technique involves heterotopic transplantation of liver segment II-III in the splenic fossa (after splenectomy) and delayed hepatectomy after regeneration of the transplanted graft 
(115). All these techniques may make resection of liver tumors feasible by combining regenerative liver surgery and liver transplantation, even when FLR is less than 20\%. However, further clinical studies are needed to critically evaluate safety and oncological outcome of these techniques.

Hepatocyte transplantation has been suggested as an liver regeneration method (116), but it is limited by shortage of donors, scarce hepatocyte viability and function in cell culture, hepatocyte susceptibility to cryopreservation damage (117), and difficult engraftment (118). Therefore, alternative cell therapies have been proposed using adult liver stem/progenitor cells, fetal liver stem cells, extrahepatic stem/progenitor cells (embryonic stem cells, induced pluripotent stem cells, and annex stem cells), and extrahepatic adult bone marrow stem cells (endothelial progenitor cells, mesenchymal stromal cells, and hematopoietic stem cells) (119). Liver tissue engineering represents another novel method to regenerate the liver by creating an implantable engineered hepatic tissue and bioartificial liver device (119).

\section{Conclusion}

ALPPS represents a breakthrough in regenerative liver surgery as is induces a very strong liver-regenerative response. It is therefore suitable for patients with extensive, otherwise unresectable hepatobiliary malignancies if careful patient selection is performed. Major advantage to other forms of portal vein occlusion based regenerative liver surgery is the short interstage interval, which markedly increases resection rates and reduces drop-out of patients. Various modifications have been proposed to improve safety and applicability. These modifications should be carefully chosen on a case-by-case basis. Still, the safest way to increase the FLR is PVE, and ALPPS should be offered to patients with a very small FLR or failure of PVE. New developments of regenerative liver surgery involve combination with liver transplantation (RAPID, RAVAS). Developments in the future will most likely go in the direction of bioengineered liver tissue to overcome current limitations of liver surgery.

\section{Supportive Foundations: None}

\section{References}

1. Rous P, Larimore LD. Relation of the portal blood to liver maintenance: a demonstration of liver atrophy conditional on compensation. J Exp Med. 1920;31(5):609-32

2. Makuuchi M, Thai BL, Takayasu K, Takayama T, Kosuge T, Gunvén P, et al. Preoperative portal embolization to increase safety of major hepatectomy for hilar bile duct carcinoma: a preliminary report. Surgery. 1990;107(5):521-7.

3. de Santibañes E, Alvarez FA, Ardiles V. How to avoid postoperative liver failure: a novel method. World J Surg. 2012;36(1):125-8.

4. Pandanaboyana S, Bell R, Hidalgo E, Toogood G, Prasad KR, Bartlett A, et al. A systematic review and meta-analysis of portal vein ligation versus portal vein embolization for elective liver resection. Surgery. 2015;157(4): 690-8.

5. Adam R, Laurent A, Azoulay D, Castaing D, Bismuth H. Two-stage hepatectomy: A planned strategy to treat irresectable liver tumors. Ann Surg. 2000; 232(6):777-85.

6. Jaeck D BP, Nakano $H$, Oussoultzoglou E, Weber JC, Wolf $P$, Greget M. One or two-stage hepatectomy combined with portal vein embolization for initially nonresectable colorectal liver metastases. Am J Surg. 2003;185(3): 221-9.

7. Kianmanesh R, Farges O, Abdalla EK, Sauvanet A, Ruszniewski P, Belghiti J. Right portal vein ligation: a new planned two-step all-surgical approach for complete resection of primary gastrointestinal tumors with multiple bilateral liver metastases. J Am Coll Surg. 2003;197(1):164-70.

8. Imai $\mathrm{K}$, Adam $\mathrm{R}, \mathrm{Baba} \mathrm{H}$. How to increase the resectability of initially unresectable colorectal liver metastases: A surgical perspective. Ann Gastroenterol Surg. 2019;3(5):476-86.

9. Schnitzbauer AA, Lang SA, Goessmann H, Nadalin S, Baumgart J, Farkas $S A$, et al. Right portal vein ligation combined with in situ splitting induces rapid left lateral liver lobe hypertrophy enabling 2-staged extended right hepatic resection in small-for-size settings. Ann Surg. 2012;255(3):405-14.

10. de Santibanes E, Clavien PA. Playing Play-Doh to prevent postoperative liver failure: the "ALPPS" approach. Ann Surg. 2012;255(3):415-7.

11. Enne M, Schadde E, Björnsson B, Hernandez Alejandro R, Steinbruck K, Viana $E$, et al. ALPPS as a salvage procedure after insufficient future liver remnant hypertrophy following portal vein occlusion. HPB (Oxford). 2017; 19(12):1126-9.

12. Björnsson B, Hasselgren K, Røsok B, Larsen PN, Urdzik J, Schultz NA, et al. Segment 4 occlusion in portal vein embolization increase future liver remnant hypertrophy - A Scandinavian cohort study. Int J Surg. 2020:75:60-5.

13. van Gulik TM, van den Esschert JW, de Graaf W, van Lienden KP, Busch OR, Heger $M$, et al. Controversies in the use of portal vein embolization. Dig Surg. 2008;25(6):436-44.

14. Coco D, Leanza S. Associating liver partition and portal vein ligation for staged hepatectomy (ALPPS) in colorectal liver metastases: review of the literature. Clin Exp Hepatol. 2021;7(2):125-33.

15. Panaro F, Giannone F, Riviere B, Sgarbura O, Cusumano C, Deshayes E, et al. Perioperative impact of liver venous deprivation compared with portal venous embolization in patients undergoing right hepatectomy: preliminary results from the pioneer center. Hepatobiliary Surg Nutr. 2019;8(4):329-37.

16. Dupré A, Hitier M, Peyrat P, Chen Y, Meeus P, Rivoire M. Associating portal embolization and artery ligation to induce rapid liver regeneration in staged hepatectomy. Br J Surg. 2015;102(12):1541-50.

17. Schadde E, Ardiles V, Slankamenac K, Tschuor C, Sergeant G, Amacker N, et al. ALPPS offers a better chance of complete resection in patients with primarily unresectable liver tumors compared with conventional-staged hepatectomies: results of a multicenter analysis. World J Surg. 2014;38(6): $1510-9$. 
18. Matsuo K, Murakami T, Kawaguchi D, Hiroshima Y, Koda K, Yamazaki K, et al. Histologic features after surgery associating liver partition and portal vein ligation for staged hepatectomy versus those after hepatectomy with portal vein embolization. Surgery. 2016;159(5):1289-98.

19. Olthof PB, Tomassini F, Huespe PE, Truant S, Pruvot FR, Troisi RI, et al Hepatobiliary scintigraphy to evaluate liver function in associating liver partition and portal vein ligation for staged hepatectomy: Liver volume overestimates liver function. Surgery. 2017;162(4):775-83.

20. Lodge JP. ALPPS: The argument for. Eur J Surg Oncol. 2017;43(2):246-8.

21. Petrowsky $H$, Györi $G$, de Oliveira M, Lesurtel M, Clavien PA. Is partial-ALPPS safer than ALPPS? A single-center experience. Ann Surg. 2015;261(4):e90-2.

22. Alvarez FA, Ardiles V, de Santibañes M, Pekolj J, de Santibañes E. Associating liver partition and portal vein ligation for staged hepatectomy offers high oncological feasibility with adequate patient safety: a prospective study at a single center. Ann Surg. 2015;261(4):723-32.

23. Tanaka K, Kikuchi Y, Kawaguchi D, Murakami T, Hiroshima Y, Matsuo K Modified ALPPS Procedures Avoiding Division of Portal Pedicles. Ann Surg. 2017;265(2):e14-e20.

24. Li J, Kantas A, Ittrich H, Koops A, Achilles EG, Fischer L, et al. Avoid "AllTouch" by Hybrid ALPPS to Achieve Oncological Efficacy. Ann Surg. 2016 263(1):e6-7.

25. de Santibanes E, Alvarez FA, Ardiles V, Pekolj J, de Santibanes M. Inverting the ALPPS paradigm by minimizing first stage impact: the Mini-ALPPS technique. Langenbecks Arch Surg. 2016;401(4):557-63.

26. Sakamoto Y, Inagaki F, Omichi K, Ohkura N, Hasegawa K, Kokudo N Associating Liver Partial Partition and Transileocecal Portal Vein Embolization for Staged Hepatectomy. Ann Surg. 2016;264(6):e21-e2.

27. Gall TM, Sodergren MH, Frampton AE, Fan R, Spalding DR, Habib NA, et al. Radio-frequency-assisted Liver Partition with Portal vein ligation (RALPP) for liver regeneration. Ann Surg. 2015;261(2):e45-6.

28. Robles R, Parrilla P, Lopez-Conesa A, Brusadin R, de la Pena J, Fuster M, et al. Tourniquet modification of the associating liver partition and porta ligation for staged hepatectomy procedure. Br J Surg. 2014;101(9):112934; discussion 34

29. Xiao L, Li JW, Zheng SG. Totally laparoscopic ALPPS in the treatment of cirrhotic hepatocellular carcinoma. Surg Endosc. 2015;29(9):2800-1.

30. Fiorentini G, Ratti F, Cipriani F, Quattromani R, Catena M, Paganelli M, et al. The SMART-ALPPS Protocol: Strategy to Minimize ALPPS Risks by Targeting Invasiveness. Ann Surg Oncol. 2021

31. Fernandes ESM, de Barros F, Magistri P, Di Sandro S, Rezende de Carvalho P, Roza da Silva F, et al. Total robotic ALPPS approach for hepatocellular carcinoma in cirrhotic liver. Int J Med Robot. 2021;17(3):e2238.

32. Hu MG, Wang J, Yin ZZ, Liu R. First two-stage robotic ALPPS in HCC patients with hepatic vein invasion: a step-by-step procedure from a clinical case. World J Surg Oncol. 2021;19(1):58.

33. Dondorf F, Deeb AA, Bauschke A, Felgendreff P, Tautenhahn HM Ardelt $\mathrm{M}$, et al. Ligation of the middle hepatic vein to increase hypertrophy induction during the ALPPS procedure. Langenbecks Arch Surg. 2021; 406(4):1111-8.

34. Murtha-Lemekhova A, Fuchs J, Schulz E, Sterkenburg A, Probst P Hoffmann K. Pushing the limit of liver regeneration - Safety and survival after monosegment-ALPPS: systematic review and individual patient data meta-analysis. HPB (Oxford). 2021.

35. Schadde E, Malago M, Hernandez-Alejandro R, Li J, Abdalla E, Ardiles V, et al. Monosegment ALPPS hepatectomy: extending resectability by rapid hypertrophy. Surgery. 2015;157(4):676-89.

36. Gauzolino R, Castagnet M, Blanleuil ML, Richer JP. The ALPPS technique for bilateral colorectal metastases: three "variations on a theme". Updates Surg. 2013;65(2):141-8.

37. Sandstrom P, Rosok BI, Sparrelid E, Larsen PN, Larsson AL, Lindell G, et al ALPPS Improves Resectability Compared With Conventional Two-stage Hepatectomy in Patients With Advanced Colorectal Liver Metastasis: Results From a Scandinavian Multicenter Randomized Controlled Trial (LIGRO Trial). Ann Surg. 2018;267(5):833-40.

38. Rosok BI, Host-Brunsell T, Brudvik KW, Carling U, Dorenberg E, Bjornsson $B$, et al. Characterization of early recurrences following liver resection by
ALPPS and two stage hepatectomy in patients with colorectal livermetastases and small future liver remnants; a translational substudy of the LIGRO-RCT. HPB (Oxford). 2019;21(8):1017-23.

39. Hasselgren K, Rosok BI, Larsen PN, Sparrelid E, Lindell G, Schultz NA, et al. ALPPS Improves Survival Compared With TSH in Patients Affected of CRLM: Survival Analysis From the Randomized Controlled Trial LIGRO. Ann Surg. 2021;273(3):442-8.

40. Petrowsky H, Linecker M, Raptis DA, Kuemmerli C, Fritsch R, Kirimker OE, et al. First Long-term Oncologic Results of the ALPPS Procedure in a Large Cohort of Patients With Colorectal Liver Metastases. Ann Surg. 2020; 272(5):793-800.

41. Li J, Moustafa M, Linecker M, Lurje G, Capobianco I, Baumgart J, et al. ALPPS for Locally Advanced Intrahepatic Cholangiocarcinoma: Did Aggressive Surgery Lead to the Oncological Benefit? An International Multicenter Study. Ann Surg Oncol. 2020;27(5):1372-84.

42. Linecker M, Kambakamba P, Raptis DA, Malago M, Ratti F, Aldrighetti L, et al. ALPPS in neuroendocrine liver metastases not amenable for conventional resection - lessons learned from an interim analysis of the International ALPPS Registry. HPB (0xford). 2020;22(4):537-44.

43. Alexandrescu S SL, Grigorie R, Tomescu D, Dobrea C, Popescu I, Hrehoret D. Primary Hepatic Lymphoma Resected by ALPPS Procedure (Associating Liver Partition and Portal Vein Ligation for Staged Hepatectomy). JTMR 21(2):153-158

44. D'Haese JG, Neumann J, Weniger M, Pratschke S, Bjornsson B, Ardiles V, et al. Should ALPPS be Used for Liver Resection in Intermediate-Stage HCC? Ann Surg Oncol. 2016;23(4):1335-43.

45. Chan A, Zhang WY, Chok K, Dai J, Ji R, Kwan C, et al. ALPPS Versus Portal Vein Embolization for Hepatitis-related Hepatocellular Carcinoma: A Changing Paradigm in Modulation of Future Liver Remnant Before Major Hepatectomy. Ann Surg. 2021;273(5):957-965.

46. Balci D, Sakamoto Y, Li J, Di Benedetto F, Kirimker E0, Petrowsky H. Associating liver partition and portal vein ligation for staged hepatectomy (ALPPS) procedure for cholangiocarcinoma. Int J Surg. 2020;82S:97-102.

47. Olthof PB, Coelen RJS, Wiggers JK, Groot Koerkamp B, Malago M, Hernandez-Alejandro R, et al. High mortality after ALPPS for perihilar cholangiocarcinoma: case-control analysis including the first series from the international ALPPS registry. HPB (Oxford). 2017:19(5):381-7.

48. Sakamoto Y, Matsumura M, Yamashita S, Ohkura N, Hasegawa K, Kokudo N. Partial TIPE ALPPS for Perihilar Cancer. Ann Surg. 2018:267(2):e18-e20.

49. Li J, Yang GS, Sun KJ, Ma Y, Bi XW, Han X. Clinical evaluation of modified ALPPS procedures based on risk-reduced strategy for staged hepatectomy. Ann Hepatol. 2021;20:100245.

50. Vennarecci G, Grazi GL, Sperduti I, Busi Rizzi E, Felli E, Antonini M, et al. ALPPS for primary and secondary liver tumors. Int J Surg. 2016;30:38-44.

51. Kambakamba P, Hoti E, Cremen S, Braun F, Becker T, Linecker M. The evolution of surgery for colorectal liver metastases: A persistent challenge to improve survival. Surgery. 2021;S0039-6060(21)00644-9. Online ahead of print.

52. Torzilli G, Cimino MM. Extending the Limits of Resection for Colorectal Liver Metastases ENHANCED ONE STAGE SURGERY. J Gastrointest Surg. 2017;21(1):187-9.

53. Botea F, Ionescu M, Brasoveanu V, Hrehoret D, Alexandrescu S, Grigorie M, et al. Liver Resections in a High-Volume Center: Form Standard Procedures to Extreme Surgery and Ultrasound-guided Resections. Chirurgia (Bucur). 2017;112(3):259-77.

54. Imai K, Allard MA, Castro Benitez C, Vibert E, Sa Cunha A, Cherqui D, et al. Long-term outcomes of radiofrequency ablation combined with hepatectomy compared with hepatectomy alone for colorectal liver metastases. Br J Surg. 2017:104(5):570-9.

55. Ko S, Kirihataya Y, Matsusaka M, Mukogawa T, Ishikawa H, Watanabe A. Parenchyma-Sparing Hepatectomy with Vascular Reconstruction Techniques for Resection of Colorectal Liver Metastases with Major Vascular Invasion. Ann Surg Oncol. 2016;23(Suppl 4):501-7.

56. Minagawa M, Makuuchi M, Torzilli G, Takayama T, Kawasaki S, Kosuge T, et al. Extension of the frontiers of surgical indications in the treatment of liver metastases from colorectal cancer: Iong-term results. Ann Surg. 2000; 231(4):487-99 
57. Torzilli G, Montorsi M, Donadon M, Palmisano A, Del Fabbro D, Gambetti $A$, et al. "Radical but conservative" is the main goal for ultrasonographyguided liver resection: prospective validation of this approach. J Am Coll Surg. 2005:201(4):517-28

58. Viganò L, Costa G, Cimino MM, Procopio F, Donadon M, Del Fabbro D, et al. R1 Resection for Colorectal Liver Metastases: a Survey Questioning Surgeons about Its Incidence, Clinical Impact, and Management. J Gastrointest Surg. 2018;22(10):1752-63.

59. Donadon M, Terrone A, Procopio F, Cimino M, Palmisano A, Viganò L, et al. Is R1 vascular hepatectomy for hepatocellular carcinoma oncologically adequate? Analysis of 327 consecutive patients. Surgery. 2019;165(5): 897-904.

60. Torzilli G, Viganò L, Fontana A, Procopio F, Terrone A, Cimino MM, et al. Oncological outcome of R1 vascular margin for mass-forming cholangiocarcinoma. A single center observational cohort analysis. HPB (Oxford). 2020;22(4):570-7.

61. Kuramitsu K, Fukumoto T, Kobayashi T, Fukushima K, Okimoto S, Iwasaki T, et al. The Incidence of Posthepatectomy Liver Failure Defined by the International Study Group of Liver Surgery among Living Donors. J Gastrointest Surg. 2016;20(4):757-64.

62. Rahbari NN, Garden OJ, Padbury R, Brooke-Smith M, Crawford M, Adam R, et al. Posthepatectomy liver failure: a definition and grading by the International Study Group of Liver Surgery (ISGLS). Surgery. 2011;149(5): 713-24.

63. Fukushima K, Fukumoto T, Kuramitsu K, Kido M, Takebe A, Tanaka M, et al. Assessment of ISGLS definition of posthepatectomy liver failure and its effect on outcome in patients with hepatocellular carcinoma. J Gastrointest Surg. 2014;18(4):729-36.

64. Dahm F, Georgiev P, Clavien PA. Small-for-size syndrome after partial liver transplantation: definition, mechanisms of disease and clinical implications. Am J Transplant. 2005;5(11):2605-10.

65. Balzan S, Belghiti J, Farges 0, Ogata S, Sauvanet A, Delefosse D, et al. The "50-50 criteria" on postoperative day 5 : an accurate predictor of liver failure and death after hepatectomy. Ann Surg. 2005;242(6):824-8, discussion 8-9.

66. Duwe G, Knitter S, Pesthy S, Beierle AS, Bahra M, Schmelzle M, et al. Hepatotoxicity following systemic therapy for colorectal liver metastases and the impact of chemotherapy-associated liver injury on outcomes after curative liver resection. Eur J Surg Oncol. 2017;43(9):1668-81.

67. Clavien PA, Petrowsky H, DeOliveira ML, Graf R. Strategies for safer liver surgery and partial liver transplantation. N Engl J Med. 2007;356(15): 1545-59.

68. Stockmann M, Lock JF, Malinowski M, Niehues SM, Seehofer D, Neuhaus P. The LiMAx test: a new liver function test for predicting postoperative outcome in liver surgery. HPB (Oxford). 2010;12(2):139-46.

69. D'Onofrio M, De Robertis R, Demozzi E, Crosara S, Canestrini S, Pozzi Mucelli R. Liver volumetry: Is imaging reliable? Personal experience and review of the literature. World J Radiol. 2014;6(4):62-71.

70. Govil S. Pringle manouver and post-hepatectomy liver failure: chicken or egg? HPB (Oxford). 2021.

71. Xing Y, Liu ZR, Yu W, Zhang HY, Song MM. Risk factors for post-hepatectomy liver failure in 80 patients. World J Clin Cases. 2021;9(8):1793-802.

72. Bae JS, Lee DH, Yoo J, Yi NJ, Lee KW, Suh KS, et al. Association between spleen volume and the post-hepatectomy liver failure and overall survival of patients with hepatocellular carcinoma after resection. Eur Radiol. 2021; 31(4):2461-71.

73. Hoffmann K, Nagel AJ, Tanabe K, Fuchs J, Dehlke K, Ghamarnejad O, et al. Markers of liver regeneration-the role of growth factors and cytokines: a systematic review. BMC Surg. 2020;20(1):31.

74. Barrera-Saldaña HA, Fernández-Garza LE, Barrera-Barrera SA. Liquid biopsy in chronic liver disease. Ann Hepatol. 2021;20:100197.

75. Myronovych A, Murata S, Chiba M, Matsuo R, Ikeda O, Watanabe M, et al. Role of platelets on liver regeneration after $90 \%$ hepatectomy in mice. J Hepatol. 2008:49(3):363-72.

76. Nakamura T, Mizuno S. The discovery of hepatocyte growth factor (HGF) and its significance for cell biology, life sciences and clinical medicine. Proc Jpn Acad Ser B Phys Biol Sci. 2010;86(6):588-610.

77. Kaibori M, Yanagida H, Nakanishi H, Ozaki T, Yoshida H, Matsui K, et al.
Hepatocyte growth factor stimulates the induction of cytokine-induced neutrophil chemoattractant through the activation of NF-kappaB in rat hepatocytes. J Surg Res. 2006;130(1):88-93.

78. Mitchell C, Nivison M, Jackson LF, Fox R, Lee DC, Campbell JS, et al. Heparin-binding epidermal growth factor-like growth factor links hepatocyte priming with cell cycle progression during liver regeneration. J Biol Chem. 2005;280(4):2562-8.

79. Lohela M, Bry M, Tammela T, Alitalo K. VEGFs and receptors involved in angiogenesis versus lymphangiogenesis. Curr Opin Cell Biol. 2009;21(2): $154-65$.

80. Shi L, Banerjee D, Dobierzewska A, Sathishkumar S, Karakashian AA, Giltiay $\mathrm{NV}$, et al. Direct regulation of IGF-binding protein 1 promoter by interleukin$1 \beta$ via an insulin- and Fox0-1-independent mechanism. Am J Physiol Endocrinol Metab. 2016;310(8):E612-E23.

81. Böhm F, Köhler UA, Speicher T, Werner S. Regulation of liver regeneration by growth factors and cytokines. EMBO Mol Med. 2010;2(8):294-305.

82. Fagiani E CG. Angiopoietins in angiogenesis. Cancer Lett. 2013;328(1): 18-26.

83. Wipff PJ HB. Integrins and the activation of latent transforming growth factor beta1 - an intimate relationship. Eur J Cell Biol. 2008;87(8-9):601-15.

84. Qidwai T, Khan F. Tumour necrosis factor gene polymorphism and disease prevalence. Scand J Immunol. 2011;74(6):522-47.

85. Liu T, Zhang L, Joo D, Sun SC. NF- $\kappa$ B signaling in inflammation. Signal Transduct Target Ther. 2017;2:17023.

86. Nguyen-Lefebvre AT, Horuzsko A. Kupffer Cell Metabolism and Function. J Enzymol Metab. 2015;1(1):101.

87. Seki E, Park E, Fujimoto J. Toll-like receptor signaling in liver regeneration, fibrosis and carcinogenesis. Hepatol Res. 2011:41(7):597-610.

88. Duarte S, Baber J, Fujii T, Coito AJ. Matrix metalloproteinases in liver injury, repair and fibrosis. Matrix Biol. 2015:44-46:147-56

89. Scholzen T, Gerdes J. The Ki-67 protein: from the known and the unknown. J Cell Physiol. 2000;182(3):311-22.

90. Wang H, Wang Z, Wang Y, Li X, Yang W, Wei S, et al. miRNA-130b-5p promotes hepatic stellate cell activation and the development of liver fibrosis by suppressing SIRT4 expression. J Cell Mol Med. 2021;25(15):7381-94.

91. Tu Y, Chen D, Pan T, Chen Z, Xu J, Jin L, et al. Inhibition of miR-431-5p attenuated liver apoptosis through KLF15/p53 signal pathway in S100 induced autoimmune hepatitis mice. Life Sci. 2021;280:119698.

92. Michalopoulos GK. Liver regeneration. J Cell Physiol. 2007;213(2):286300.

93. Taub R. Liver regeneration: from myth to mechanism. Nat Rev Mol Cell Biol. 2004:5(10):836-47

94. GRISHAM JW. A morphologic study of deoxyribonucleic acid synthesis and cell proliferation in regenerating rat liver; autoradiography with thymidineH3. Cancer Res. 1962;22:842-9.

95. Nelsen CJ, Rickheim DG, Tucker MM, Hansen LK, Albrecht JH. Evidence that cyclin D1 mediates both growth and proliferation downstream of TOR in hepatocytes. J Biol Chem. 2003;278(6):3656-63.

96. Abshagen K, Eipel C, Vollmar B. A critical appraisal of the hemodynamic signal driving liver regeneration. Langenbecks Arch Surg. 2012;397(4):57990

97. Mortensen KE, Conley LN, Nygaard I, Sorenesen P, Mortensen E, Bendixen $C$, et al. Increased sinusoidal flow is not the primary stimulus to liver regeneration. Comp Hepatol. 2010;9:2.

98. Wilms C, Mueller L, Lenk C, Wittkugel O, Helmke K, Krupski-Berdien G, et al. Comparative study of portal vein embolization versus portal vein ligation for induction of hypertrophy of the future liver remnant using a mini-pig model. Ann Surg. 2008:247(5):825-34.

99. Schadde E, Guiu B, Deal R, Kalii J, Arslan B, Tasse J, et al. Simultaneous hepatic and portal vein ligation induces rapid liver hypertrophy: A study in pigs. Surgery. 2019;165(3):525-33

100. Tanaka K, Matsuo K, Murakami T, Kawaguchi D, Hiroshima Y, Koda K, et al. Associating liver partition and portal vein ligation for staged hepatectomy (ALPPS): short-term outcome, functional changes in the future liver remnant, and tumor growth activity. Eur J Surg Oncol. 2015;41(4):506-12.

101. Dhar DK, Mohammad GH, Vyas S, Broering DC, Malago M. A novel rat model of liver regeneration: possible role of cytokine induced neutrophil 
chemoattractant-1 in augmented liver regeneration. Ann Surg Innov Res. 2015:9:11.

102. Shindoh J, Vauthey JN, Zimmitti G, Curley SA, Huang SY, Mahvash A, et al. Analysis of the efficacy of portal vein embolization for patients with extensive liver malignancy and very low future liver remnant volume, including a comparison with the associating liver partition with portal vein ligation for staged hepatectomy approach. J Am Coll Surg. 2013;217(1) 126-33; discussion 33-4.

103. Schlegel A, Lesurtel M, Melloul E, Limani P, Tschuor C, Graf R, et al. ALPPS from human to mice highlighting accelerated and novel mechanisms of liver regeneration. Ann Surg. 2014;260(5):839-46; discussion 46-7.

104. Wei W, Zhang T, Zafarnia S, Schenk A, Xie C, Kan C, et al. Establishment of a rat model: Associating liver partition with portal vein ligation for staged hepatectomy. Surgery. 2016;159(5):1299-307.

105. Schwabe RF, Bradham CA, Uehara T, Hatano E, Bennett BL, Schoonhoven R et al. c-Jun-N-terminal kinase drives cyclin D1 expression and proliferation during liver regeneration. Hepatology. 2003:37(4):824-32

106. Shi H, Yang G, Zheng T, Wang J, Li L, Liang Y, et al. A preliminary study of ALPPS procedure in a rat model. Sci Rep. 2015;5:17567.

107. García-Pérez R, Revilla-Nuin B, Martínez CM, Bernabé-García A, Baroja Mazo A, Parrilla Paricio P. Associated Liver Partition and Portal Vein Ligation (ALPPS) vs Selective Portal Vein Ligation (PVL) for Staged Hepatectomy in a Rat Model. Similar Regenerative Response? PLoS One. 2015;10(12):e0144096.

108. Wildhaber BE, Terraz S. Portal vein embolization in children: As good as ALPPS. Ann Hepatobiliary Pancreat Surg. 2021;25(2):313-4.

109. Paschos KA, Bird NC. Liver regeneration and its impact on post-hepatectomy metastatic tumour recurrence. Anticancer Res. 2010;30(6):2161-70.

110. Yokoyama N, Shirai Y, Ajioka Y, Nagakura S, Suda T, Hatakeyama K.
Immunohistochemically detected hepatic micrometastases predict a high risk of intrahepatic recurrence after resection of colorectal carcinoma liver metastases. Cancer. 2002;94(6):1642-7.

111. Townson JL, Chambers AF. Dormancy of solitary metastatic cells. Cell Cycle. 2006;5(16):1744-50.

112. Kambakamba P, Linecker M, Schneider M, Reiner CS, Nguyen-Kim TDL, Limani $P$, et al. Impact of associating liver partition and portal vein ligation for staged hepatectomy (ALPPS) on growth of colorectal liver metastases. Surgery. 2018;163(2):311-7.

113. Nadalin S, Settmacher U, Rauchfuss F, Balci D, Konigsrainer A, Line PD. RAPID procedure for colorectal cancer liver metastasis. Int J Surg. 2020; 82S:93-6.

114. Line PD, Hagness M, Berstad AE, Foss A, Dueland S. A Novel Concept for Partial Liver Transplantation in Nonresectable Colorectal Liver Metastases: The RAPID Concept. Ann Surg. 2015;262(1):e5-9

115. Ravaioli M, Brandi G, Siniscalchi A, Renzulli M, Bonatti C, Fallani G, et al. Heterotopic segmental liver transplantation on splenic vessels after splenectomy with delayed native hepatectomy after graft regeneration: A new technique to enhance liver transplantation. Am J Transplant. 2021:21(2):870-5.

116. Fausto N, Campbell JS, Riehle KJ. Liver regeneration. Hepatology. 2006;43(2 Suppl 1):S45-53.

117. Stéphenne X, Najimi M, Sokal EM. Hepatocyte cryopreservation: is it time to change the strategy? World J Gastroenterol. 2010;16(1):1-14

118. Gramignoli R, Vosough M, Kannisto K, Srinivasan RC, Strom SC. Clinical hepatocyte transplantation: practical limits and possible solutions. Eur Surg Res. 2015;54(3-4):162-77.

119. Tsolaki E, Yannaki E. Stem cell-based regenerative opportunities for the liver: State of the art and beyond. World J Gastroenterol. 2015;21(43): $12334-50$. 